\title{
Environmental association of iron minerals and iron concentrations in soils close to abandoned manganese mine - a multivariate analytical approach
}

\author{
GEORGES-IVO E. EKOSSE ${ }^{1^{*}}$; PAUL S. FOUCHE ${ }^{2}$ \\ ${ }^{1}$ X-Ray Diffraction Unit, Faculty of Science, University of Botswana, P/B 0022 Gaborone, Botswana \\ ${ }^{2}$ School of Agricultural and Environmental Science, University of Limpopo, P/B 1106 Sovenga, 0727 South Africa
}

\begin{abstract}
Environmental association of iron ( $\mathrm{Fe}$ ) minerals and $\mathrm{Fe}$ concentrations in soils close to the Kgwakgwe Mn oxide ore abandoned mine, Botswana are investigated in this study. Four hundred soil samples were obtained from a $4 \mathrm{~km}^{2}$ area close to the abandoned mine. The Fe minerals in the soil samples were identified by $\mathrm{x}-$ ray diffractometry and the Fe concentrations by atomic absorption spectrophotometry. Results were processed using the statistical package for social science (SPSS). Iron minerals namely hematite and goethite were found in soils from the study area but only hematite in soils from the control site. Also Fe concentrations in soils from the study area were significantly higher than those from the control site. The correlations depicted very weak associations of these parameters. Hematite contributed significantly in the formation of the five clusters, goethite's contribution was for three of the clusters, and Fe concentrations in soils were for two of the clusters. At Kgwakgwe, exposed surfaces of mine workings, ferruginous shale and country rocks through wind erosion release particulate air matter, rich in $\mathrm{Fe}$ into the atmosphere which are transported over short distances and deposited on soils. Through chemical alteration processes, hematite is hydrated to goethite and neomineralization of goethite from the ferruginous shale occurs in the surrounding soils. @JASEM
\end{abstract}

The use of multivariate analyses in understanding different physical environments in Botswana has been limited to clays and clay minerals (Ekosse and Forcheh, 2005), manganiferous occurrences (Ekosse and Fouche, 2005, 2005a) and nickel-copper deposit (Ekosse et. al, 2005). The technique has not been applied to establish statistical relationship between $\mathrm{Fe}$ minerals and $\mathrm{Fe}$ concentrations in soils close to an abandoned Mn oxide ore mine. Manganese was mined at Kgwakgwe, south eastern Botswana from 1957 to 1987 (Ekosse, 2001; Ekosse and MulabaBafubiandi, 2003; Ekosse and Nkoma, 2002; Ekosse and Vink, 2001; Lanzincka, 1992). The geographical coordinates of Kgwakgwe are latitudes $24^{\circ} 59^{\prime}$ and $25^{\circ} 02^{\prime}$, and longitudes $25^{\circ} 17^{\prime}$ and $25^{\circ} 20^{\prime}$.

Iron occurs as an integral element in Mn orebodies. At Kgwakgwe, Fe bearing minerals (both goethite and hematite), have been identified in substantial quantities (Ekosse and Modisi, 1999). Although it is very essential in the blood, Fe may have some adverse effects to the physical environment. In the oxidation of sulphides of $\mathrm{Fe}$, acidic solutions are created which tend to decrease adsorption and promote mobility of metals in soils, water and sediments. Although many metals, including Fe are essential for plant health, they could be toxic if their concentration levels are high. High toxic levels of heavy metals in plants are manifested by reduced and stunted growth and, in extreme cases, death.

Iron and $\mathrm{Mn}$ are chemically associated, and are usually found in the same geologic environments. At the end of any minerals exploitation, the closure and decommissioning phases have to be executed. Unfortunately, this was not carried out at Kgwakgwe. Consequently, mine related environmental impacts as explained by Ashton et. al. (2001), may have continued to occur several years after the mine ceased operating. This study therefore addresses the association of $\mathrm{Fe}$ minerals and $\mathrm{Fe}$ concentrations in soils close to the abandoned mine by investigating the statistical relations of these parameters in the soils, based on a multivariate statistic approach. It attempts to elucidate on environmental mining impact on the Fe chemistry and $\mathrm{Fe}$ mineralogy of the Kgwakgwe soils from a statistical point of view.

\section{MATERIALS AND METHODS}

Mitchell (1976) and Remmelzwaal (1988) describe the Kgwakgwe soils as luvisols, with moderate, moderate-well to well drained, having brown to yellowish brown colour, and sandy loam to sandy clay texture. A control site of $900 \mathrm{~m}^{2}(300 \mathrm{~m} \times 300$ $\mathrm{m})$, separated by a paleotopographic barrier devoid of Mn mineralization, located $4 \mathrm{~km}$ south of the study area, was chosen (Ekosse and Vink, 1998). Its soil lithology and that of the study site $(2 \mathrm{~km} \times 2 \mathrm{~km})$ were very similar. The techniques and methods for soil sampling as described by Jewell et. al., (1993), Crépin and Johnson (1993) and Tan (1996, 1998) were used to obtain soil samples from both the study area and the control site. Four hundred soil samples were taken at $100 \mathrm{~m}$ intervals, and at a depth of between $0 \mathrm{~cm}$ and $20 \mathrm{~cm}$, nine samples from the control site for analyses. Three samples of ferruginous shale from the study area were also 
sampled for the identification of $\mathrm{Fe}$ minerals contained in them.

Minerals were identified using a Philips PW 3710 XRPD X-ray diffractometer system, operated at $40 \mathrm{kV}$ and $45 \mathrm{~mA}$, having a $\mathrm{Cu}-K_{\alpha}$ radiation and a graphite monochromator. A PW 1877 Automated Powder Diffraction, X'PERT Data Collector software package was employed to capture raw data, and a Philips X'PERT Graphics \& Identify software package was used for qualitative identification and semi quantitative analyses of the minerals from both the data and patterns obtained by scanning at a speed of $1^{\circ} 2 \theta / \mathrm{min}$. Samples were scanned from $2^{\circ} 2 \theta$ to $90^{\circ} 2 \theta$. The interpreted results were compared with data and patterns available in the Mineral Powder Diffraction File, data book (International Center for Diffraction Data (ICDD), 2001). Iron concentrations in the samples were determined by atomic absorption spectrophotometry after acid digestion. The procedure for sample digestion is as reported by Jones and Case (1990) and Page et. al. (1982). The identified minerals were analysed to establish their abundances through quantitative measure (numbers) where none $=0$, trace $=1$, minor $=2$ and major $=3$. Different concentrations of $\mathrm{Fe}$ in soil samples from least to most concentrated were coded 1 from 1 to 8 respectively.

The data was processed with the aid of the SPSS software. Statistical multivariate analyses as explained by Miller and Miller (2000) were performed. The analyses included descriptive statistics, frequency tables, Pearson's correlation matrix, Chi-square or t-test of significance for $95 \%$ confidence levels, the Bonferroni adjusted two-step cluster analysis, and hierarchical clustering. Cross tabulation of the Fe minerals and Fe concentrations was used to show their relationships of occurrences in the soil samples.

\section{RESULTS AND DISCUSSION}

$\mathrm{Fe}$ minerals and $\mathrm{Fe}$ concentrations: The results of XRPD analyses indicated that the ferruginous shale consisted mainly of hematite and goethite, and for the soil samples, they contained the same Fe minerals as the ferruginous shale (Table 1), and the coded concentrations of Fe in soil samples (Table 2). Out of 400 samples analysed, 197 samples contained hematite, and 114 had goethite. At the control site hematite was the only Fe bearing mineral identified (Figure 1). Table 3 presents the summary statistics of the $\mathrm{Fe}$ minerals and concentrations of $\mathrm{Fe}$ in soil samples. The range of concentration levels of $\mathrm{Fe}$ in soils was from $1116 \mu \mathrm{g} \mathrm{g}^{-1}$ to $870766 \mu \mathrm{g} \mathrm{g}^{-1}$ with a mean of $17593 \mu \mathrm{g} \mathrm{g}^{-1}$. The concentrations of $\mathrm{Fe}$ in the control area were from $2541 \mu \mathrm{g} \mathrm{g}^{-1}$ to $7887 \mu \mathrm{g} \mathrm{g}^{-}$ 1; and these values were significantly lower than the mean concentration values of soils from the study site.

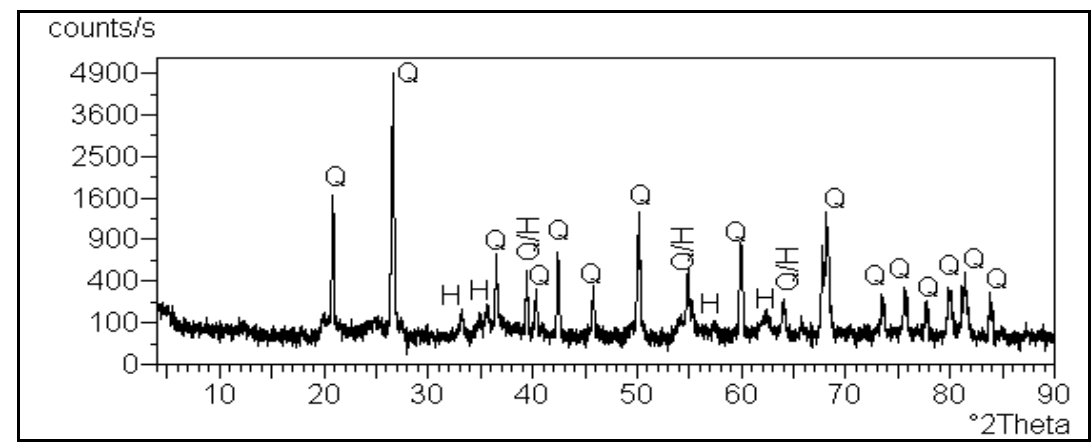

Fig 1: X-ray powder diffractogram of representative soil sample from the control site $(\mathrm{Q}=$ quartz; and $\mathrm{H}=$ hematite)

Table 1: Summary semi quantitative results of Fe minerals identified in soil samples by XRPD Chemical formula

\begin{tabular}{ccccccc} 
Mineral Group & Mineral & & Trace & Minor & Major & Total \\
\hline \multirow{2}{*}{ Fe minerals } & Hematite & $\mathrm{Fe}_{2} \mathrm{O}_{3}$ & 63 & 12 & 122 & 197 \\
& Goethite & $\mathrm{FeO} . \mathrm{OH}$ & 76 & 31 & 7 & 114 \\
\hline
\end{tabular}


Table 2: Code for Fe concentrations in soils samples.

\begin{tabular}{c|c}
\hline Code & Iron in soils $\left(\mu \mathrm{g} \mathrm{g}^{-1}\right)$ \\
\hline 1 & Below 5000 \\
2 & $5000-9999.9$ \\
3 & $10000-14999.9$ \\
4 & $15000-19999.9$ \\
5 & $20000-24999.9$ \\
6 & $25000-29999.9$ \\
7 & $30000-34999.9$ \\
8 & $>35000$ \\
\hline
\end{tabular}

Table 3: Descriptive statistics of hematite, goethite and concentrations of iron in soils samples

\begin{tabular}{cccc}
\hline Parameter & Hematite & Goethite & $\begin{array}{c}\text { Iron in } \\
\text { soils }\end{array}$ \\
\hline Mean & 1.13 & .40 & 3.38 \\
$\begin{array}{c}\text { Std. Error of } \\
\text { Mean }\end{array}$ & .066 & .035 & .075 \\
Median & $.73(\mathrm{a})$ & $.32(\mathrm{a})$ & $3.25(\mathrm{a})$ \\
Mode & 0 & 0 & 3 \\
$\begin{array}{c}\text { Std. } \\
\text { Deviation }\end{array}$ & 1.319 & .708 & 1.492 \\
\hline \multicolumn{4}{r}{ a is calculated from grouped data. }
\end{tabular}

Inferential statistics and multivariate analysis: The product moment correlation coefficients between the Fe minerals and Fe concentrations in the soil samples are shown in Table 4. In general, the correlation coefficients depicted very weak associations. The hematite/Fe in soil and goethite/Fe in soil depicted very weak correlation reflecting weak negative associations. The hematite/goethite portrays weak positive association.

Table 5 gives the cluster profile of $\mathrm{Fe}$ concentrations in soil samples, hematite and goethite, and Figure 2 reflects their $95 \%$ simultaneous confidence intervals for their means ( $\mathrm{Fe}$ concentrations, Figure 2a; hematite, 2b; goethite, 2c). Coded values (1-8) which are used in the clusters are based on real values shown in Table 2. Five clusters were obtained, and their interpretations are based on the mean values obtained for each parameter. In cluster 2 was characterized by Fe concentrations in soil, clusters 3 and 4 by hematite, and clusters 4 and 5 by goethite. Cluster 1 was characterized by none of the three parameters.

Table 4: Pearson correlation test for hematite, goethite and concentrations of iron in soils samples.

\begin{tabular}{cccc}
\hline Parameter & $\begin{array}{c}\text { Iron in } \\
\text { soils }\end{array}$ & Hematite & Goethite \\
\hline Iron in soils & 1 & -.065 & -.056 \\
Hematite & -.065 & 1 & .072 \\
Goethite & -.056 & .072 & 1 \\
\hline
\end{tabular}

Table 5: Centroids of cluster profiles of hematite, goethite and concentrations of iron in soils samples

\begin{tabular}{cccccccc}
\hline & & \multicolumn{2}{c}{ Iron in soils } & \multicolumn{2}{c}{ Hematite } & \multicolumn{2}{c}{ Goethite } \\
\cline { 3 - 7 } Cluster & $\mathrm{N}$ & Mean & $\begin{array}{c}\text { Std. } \\
\text { Deviation }\end{array}$ & Mean & $\begin{array}{c}\text { Std. } \\
\text { Deviation }\end{array}$ & Mean & $\begin{array}{c}\text { Std. } \\
\text { Deviation }\end{array}$ \\
\hline 1 & 159 & 2.83 & .929 & .19 & .397 & .00 & .000 \\
2 & 47 & 6.00 & 1.216 & .43 & .773 & .11 & .312 \\
3 & 84 & 3.29 & 1.188 & 2.98 & .153 & .00 & .000 \\
4 & 45 & 2.76 & 1.317 & 2.82 & .387 & 1.40 & .618 \\
5 & 65 & 3.38 & 1.259 & .34 & .477 & 1.42 & .610 \\
Combined & 400 & 3.38 & 1.492 & 1.13 & 1.319 & .40 & .708 \\
\hline
\end{tabular}

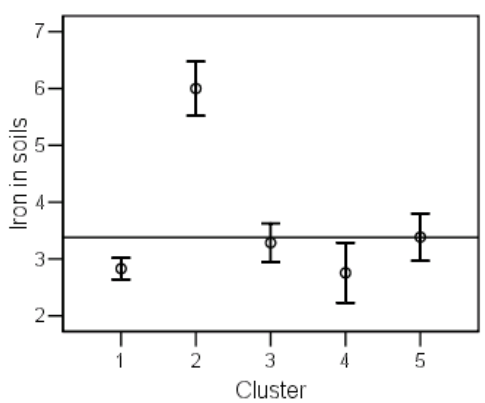

Fig 2a: Simultaneous $95 \%$ Confidence intervals for means of Fe concentrations in soils sample. 


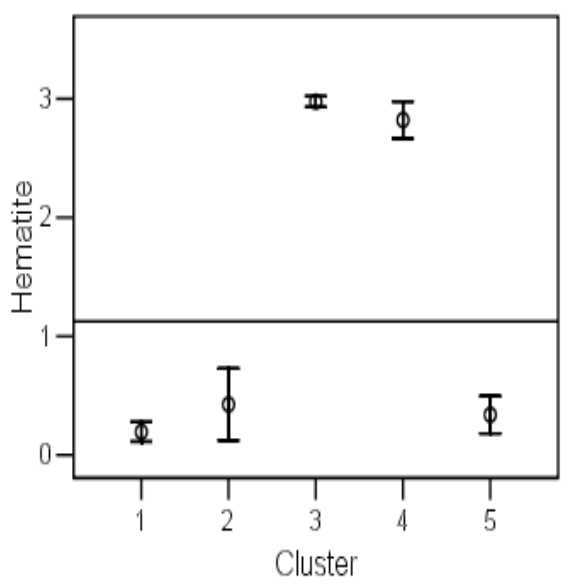

Fig 2b: Simultaneous 95\% Confidence intervals for means of hematite concentrations in soils sample.

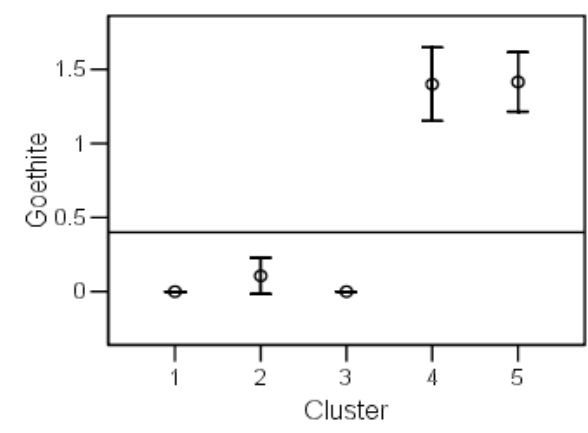

Fig 2c: Simultaneous 95\% Confidence intervals for means of goethite concentrations in soils samples.

Figures 3 is the Bonferroni Adjustment "by variable" importance charts for two step cluster analysis for hematite, goethite and Fe concentrations in the soil samples. The variables are lined up on the $\mathrm{Y}$ axis, in descending order of importance. The dashed vertical lines mark the critical values for determining the significance of each variable. For a variable to be considered significant, its $t$ statistic must exceed the dashed line in either a positive or negative direction. A negative $t$ statistic indicates that the variable generally takes smaller than average values within this cluster, while a positive $t$ statistic indicates the variable takes larger than average values. Cluster 1 shows hematite and $\mathrm{Fe}$ concentrations in soils exceeding the critical value (Figure 3a). The negative $t$ statistic for both of them indicates that the variables generally take smaller than average values within this cluster. For the formation of cluster 2, Fe concentrations in soils, was the most important followed by goethite and hematite in almost same degree of importance (Figure 3b). Positive $t$ statistic value was obtained for Fe concentrations in soils, and negative $t$ statistic values were obtained for goethite and hematite within this cluster. In cluster 3 , the importance measures for hematite exceed the critical value, and were important to the formation of the third cluster (Figure 3c). In cluster 4, hematite and goethite were the most important and the two parameters indicated positive $t$ statistic values (Figure 3d). For fifth cluster, the importance measures for hematite and goethite exceed the critical value, and whereas a positive negative $t$ statistic value was obtained for goethite, hematite on the other hand had a negative $t$ statistic value (Figure $3 \mathrm{e}$ ).

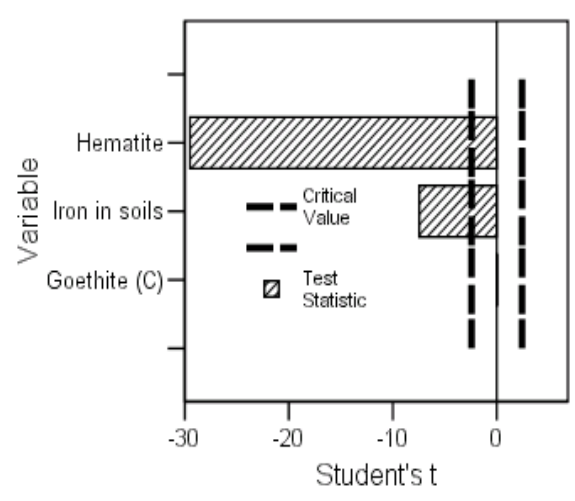

Fig 3a: Bonferroni Adjusted two step cluster of cluster one for Fe minerals and Fe concentrations in soils samples.

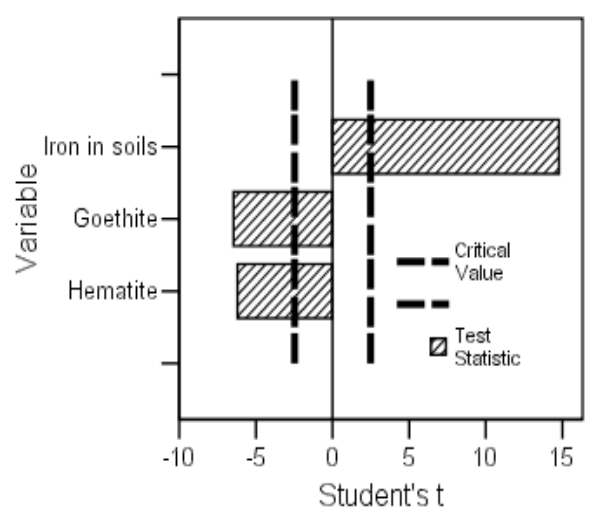

Fig 3b: Bonferroni Adjusted two step cluster of cluster two for $\mathrm{Fe}$ minerals and $\mathrm{Fe}$ concentrations in soils samples. 


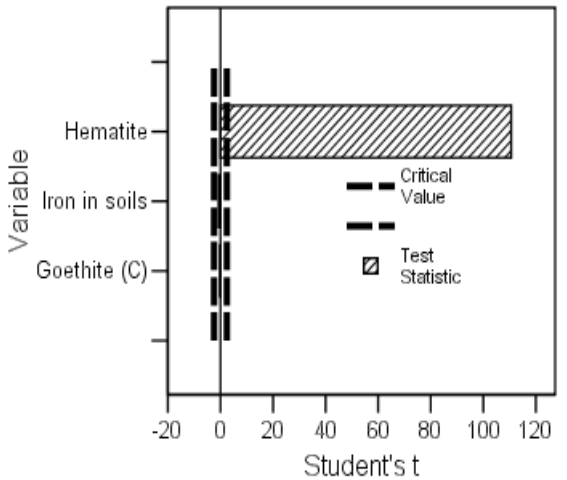

Fig 3c: Bonferroni Adjusted two step cluster of cluster three for $\mathrm{Fe}$ minerals and $\mathrm{Fe}$ concentrations in soils samples

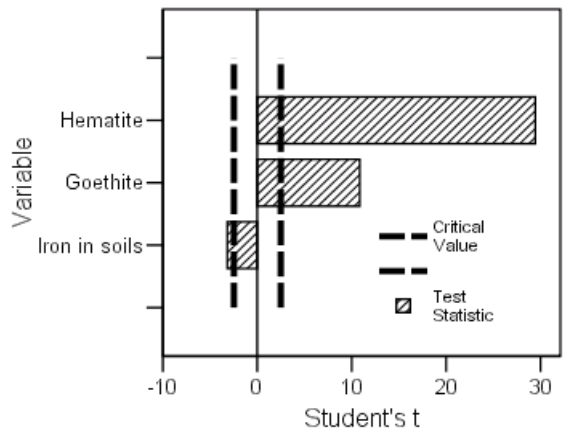

Fig 3d: Bonferroni Adjusted two step cluster of cluster four for $\mathrm{Fe}$ minerals and $\mathrm{Fe}$ concentrations in soils samples

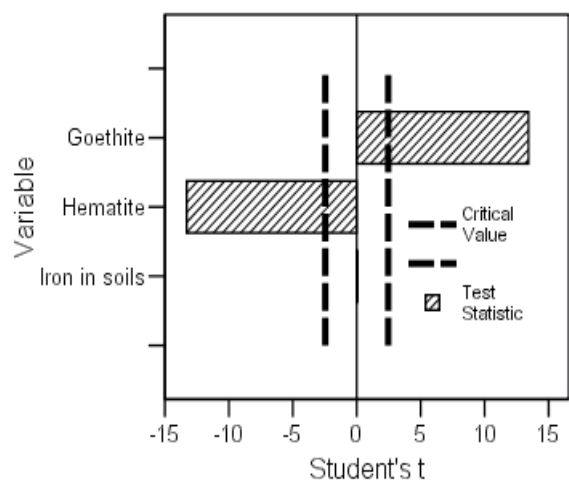

Fig 3e: Bonferroni Adjusted two step cluster of cluster five for Fe minerals and Fe concentrations in soils samples

Further complementary multivariate analysis of the soil samples using complete linkage hierarchical clustering method and correlation coefficients as a measure of similarity was performed (Figure 4). The degree of association between groups of variables is represented by the distance axis. The lower the value on the axis, the more significant the association is. Two main hierarchical clustering were obtained. Hematite and goethite are very well coordinated followed by the linking of the three parameters by $\mathrm{Fe}$ in soils at the end of the distance axis.

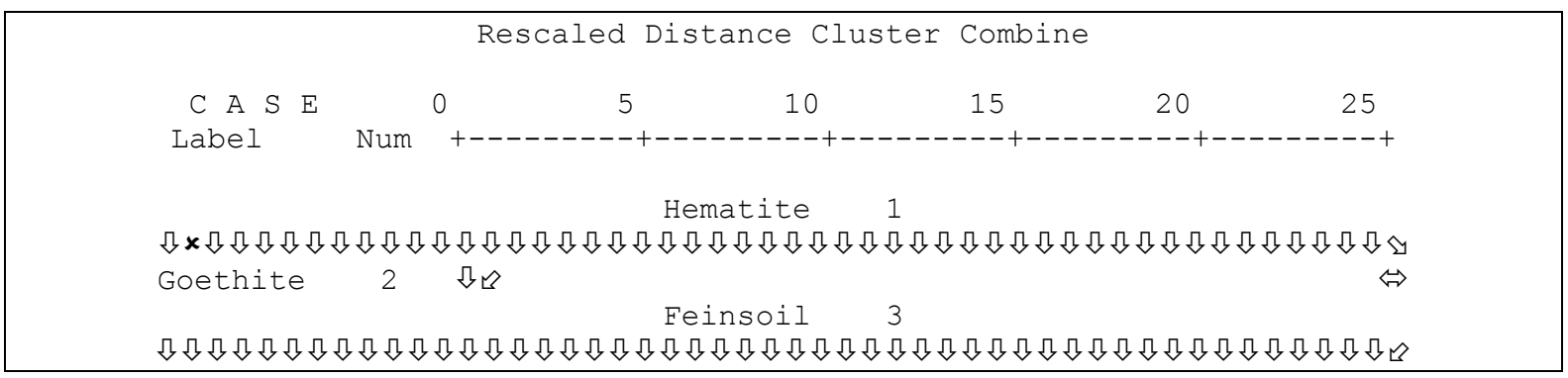

Fig 4: Dendrogram using complete linkage of hematite, goethite and concentrations of iron in soils samples.

Environmental considerations: The $\mathrm{Fe}$ concentrations and occurrence of Fe minerals in the soils of the study area were possibly influenced primarily by the $\mathrm{Fe}$ source, and weathering patterns. Due to occurrences of goethite in the sampled ferruginous shale, and the soils of the study area, but not in samples from the control site, it is evident that the source of goethite in soils was from the shale. Sediments containing exposed goethite particles eroded and were transported either by wind or water (meteoric fluids and streams) to contaminate surrounding soils especially those at the study area. Another form in which the goethitic enrichment of the soils could have been due to dissolution, saturation and neomineralisation processes (Ekosse and Modisi, 1999; Ekosse and Vink, 1998). Depending on favorable geochemical conditions, hematite from the ferruginous shale released $\mathrm{Fe}$ ions through dissolution causing the $\mathrm{Fe}$ rich fluids to follow migratory pathways, and become recrystallized as goethite as conditions changed (Ekosse and Modisi, 1999). These conditions were non existent at the control site; hence an explanation for the absence of goethite there. 


\section{REFERENCES}

Ashton P. J., Love D., Mahachi H., and Dirks P. H. G. M. (2001) An overview of the impact of mining and mineral processing operations on water resources and water quality in the Zambezi, Limpopo and Olifants catchments in southern Africa. Contract report to the Mining, Minerals and Sustainable Development (Southern Africa) project, by CSIREnvironmentek, Pretoria, South Africa and Geology Department, University of Zimbabwe, Harare, Zimbabwe. Report No. ENV-P-C 2001-042. 336 pp.

Crépin J and Johnson R.L. (1993) Soil sampling for environmental assessment. In Carter R. M. (Ed) Soil sampling and methods of analyses.

Ekosse G. (2001) Provenance of the Kgwakgwe kaolin deposit in southeastern Botswana and its possible utilization Applied Clay Science. 20, 137-152.

Ekosse G. and Forcheh N. (2005) A multivariate approach to granulometry of kaolinitic sediments from Botswana. Botswana Journal of Technology 14, (1)35-40.

Ekosse G. and Fouche P. S. (2005) Spatial distribution of manganese on Kgwakgwe vegetation cover in the proximity of an abandoned manganese oxide mine and implications for future agricultural development in the region. Land Contamination and Reclamation 13 (3) 267-273

Ekosse G. and Fouche P. S. (2005a) Multivariate analysis and spatial distribution of selected cations in soils within the proximity of an abandoned manganese mine, Kgwakgwe, Botswana. Submitted to Current Science

Ekosse G. and Modisi M. P. (1999) Mineralogical characterization, genesis and possible economic applications of goethite occurrences at the Lower Transvaal Supergroup, Kgwakgwe, Botswana. Botswana Journal of Earth Sciences. 4, 6-12.

Ekosse G. and Mulaba-Bafubiandi A. F. (2003) Kaolin occurrences in Botswana and possible uses as functional fillers. Proceedings of the $16^{\text {th }}$ Industrial Minerals International Congress, Montreal, Canada. 6-9 April 2003, 68-80.

Ekosse G., Ngila J. C. and Forcheh N. (2005) Multivariate analyses of heavy metals in soils and Colospermum mopane leaves around the Selebi Phikwe nickelcopper mine and smelter/concentrator plant, Botswana. Journal of Applied Sciences and Environmental Management 9(1)177-185
Ekosse G. and Nkoma J. S. (2002) Electron microscopy and complementary techniques in the study of kaolinite formation from localised muscovite. Proceedings of the International Conference on Electron Microscopy, Durban, South Africa. ICEM 15, 1079-1080.

Ekosse G. and Vink B. (1998) The Kgwakgwe manganese oxides in the Kanye area, southeastern Botswana evidence for a shallow aqueous palaeo-environment. Botswana Notes and Records. 30, 147-156.

Ekosse G. and Vink B. (2001) The Geology and Mineralogy of the Manganiferous, Ferrugenous and Argillaceous Sediments in the Kgwakgwe Basin, Lower Transvaal Supergroup, Kanye area, Botswana. Botswana Journal of Earth Sciences. 5, 11-20.

International Centre for Diffraction Data (2001) International Centre for Diffraction Data. Mineral Powder Diffraction File Databook. Pp 942.

Jewell M.C., Hensley P. J., Barry D.A. and Acworth I. (1993) Site investigation and monitoring techniques for contaminated sites and potential waste disposal sites. In Fell R., Philips T., Gerrad C., (Eds) Geotechnical management of waste and contamination.

Jones J. B. and Case V. W. (1990) Sampling, Handling and Analyzing Plant Tissue Samples, In; Soil Testing and Plant Analysis, 3rd Ed., R.L. Westerman, Ed., Soil Science Society of America, Inc., Madison WI, pp.389 $-427$

Lanzincka P. (1992) Manganese deposits in the global lithogenic system: Quantitative approach. Ore Geology Review. 7, 279-356.

Miller J. N. and Miller J. C. (2000) Statistics and chemometrics for analytical chemistry. $4^{\text {th }}$ Edition. Prentice Hall, England, pp168-9.

Mitchell A. J. B. (1976) Soil description and analysis from Eastern Botswana. Land Res. Div. Min. of Overseas Dev. Tolworth, England. Supplementary Report 6.

Page A. L., Miller, R. H. and Keeney, D. R. (1982) Methods of Soil Analysis, Part 2. Chemical and Microbiological Properties, $2^{\text {nd }}$ Ed. America Society of Agronomy Inc. USA.

Reemelwaal A. (1988) General soil legend of Botswana. FAO/UNDP/Gov't of Botswana. Field document. $\mathrm{BOT} / 85 / 11$

Tan K. H. (1996) Sample preparation. In Dekker M. (Ed), Soil sample preparation and analysis.14pp.

Tan K. H. (1998) Principles of soil chemistry. Mariel Dekker Inc. USA. $521 \mathrm{pp}$. 